\title{
Mechanism, Implementation, and Challenges in Independent Campus Education Policy in Indonesia
}

\author{
Deding Ishak \\ STAI YAPATA Al-Jawami, Bandung, Indonesia \\ Email: dedingishak@yahoo.com
}

\begin{abstract}
The Independent Learning-Independent Campus Policy was issued by the Minister of Education and Culture of the Republic of Indonesia, Nadiem Anwar Makarim. The policy aims to improve the competence of graduates, both soft skills and hard skills, to be more prepared and relevant to the needs of the times, to prepare graduates as future leaders of the nation with excellent and personalities. "Freedom of Learning, Independent Campus" policy includes the opening of new study programs, a higher education accreditation system, the freedom to become a PTN-BH, and the right to study for three semesters outside the study program. This policy of the Minister of Education and Culture deserves to be called a reasonably extreme change. This then raises some doubts in the minds of academics. The method used by the author in this study is a literature study approach. In this method, data is collected through a literature study, analyzed, and presented in the discussion. The study results show that the visionary policy of the Minister of Education and Culture deserves to be appreciated. Still, several problems arise from implementing the "Independent Learning, Independent Campus" policy that must be immediately resolved.
\end{abstract}

Keywords: Independent Campus, Education Policy, Mechanism, Implementation, Challenges.

\section{A. INTRODUCTION}

The development of the modern world is currently snowballing. These developments pose serious challenges for the younger generation (Digdowiseiso, 2020). The global world in the era of 4.0 and 5.0 has an impact that is not simple. It affects all aspects of human life, including education. This era is marked by the central role of technology and information in human life (Digdowiseiso, 2018). Era 4.0 gave birth to education 4.0. This concept arose because of changing skill requirements due to the industrial era 4.0. This is a vision of the future of education, which response to the needs of Industry 4.0. Education 4.0 is known as an innovation characterized by being student-centered (Morrar et al., 2017). This approach can develop knowledgeable students and create new mindsets that can respond to life's challenges and increase creativity and innovation in various aspects of life (Jaenuddin et al., 2020).

But unfortunately, many places of education for students to study, such as universities, still have difficulty moving forward to become better. This is because there are problems for universities, especially private universities (PTS), the lack of education budgets, and the complicated government bureaucracy and the higher education curriculum system that tends to be centralized to limit universities to 
radical innovation (Suharyono \& Digdowiseiso, 2021). The appointment of Nadiem Makarim as Minister of Education and Culture provides a glimmer of hope for private universities in Indonesia. With the idea of "Freedom of Learning," there is optimism among private universities to develop rapidly and autonomously innovate for the development of all aspects of higher education (Dunaev et al., 2018). However, this policy also raises several questions regarding applying the concept of independent learning at a practical level.

There is an exciting expression from Nadiem Anwar Makarim regarding the freedom of learning. "Giving freedom and autonomy to educational institutions, and independence from bureaucratization, lecturers are freed from complicated bureaucracy and students are given the freedom to choose the fields they like," said the Minister of Education and Culture (Prahani et al., 2020). From that expression, a policy entitled "Independence of Learning-Independent Campus" was issued. The Independent Learning Policy-Independent Campus aims to improve the competence of graduates, both soft skills and hard skills, to be more prepared and relevant to the needs of the times, preparing graduates as future leaders of the nation with superior and personalities. Experiential learning programs with flexible pathways are expected to facilitate students to develop their potential according to their passions and talents (Hidayat et al., 2021)

The Independent Campus policy will certainly provide various facilities for the world of education in Indonesia, both for students and teaching staff (Sandy, 2018). However, this policy can then provide new questions regarding how the implementation of cooperation between campuses with various backgrounds with external parties, how the mechanism of student exchange occurs with different geographical, economic conditions and the quality of human resources, and how to guarantee quality as a result of the emergence of the new accreditation system. Through these questions, researchers are interested in researching the mechanisms, implementation, and challenges of Indonesia's Independent Campus education policy.

\section{B. LITERATURE REVIEW}

\section{Education policy}

Many parties understand education policy as a collection of laws or regulations that regulate the implementation of the education system, including the objectives, processes, evaluation, and follow-up of education so that there is no conflict of interest between citizens in fulfilling their rights and obligations (Rao et al, 2020). Carter V. Good defines educational policy as judgment, derived from some system of values and some assessment of situational factors, operating within institutionalized education as a general plan for guiding decisions regarding attaining desired educational objectives (Posselt et al., 2020). The same thing is explained by Hasbullah, who stated that education policy is the whole process and result of the formulation of educational strategy steps that are described from the vision and mission of education, 
to realize the achievement of educational goals in a society for a certain period (Radianti et al., 2020).

Then, H.A.R Tilaar \& Riant Nugroho explained that education policy is the key to excellence, even existence, for the nation-state in global competition, so education policy needs to get top priority in the era of globalization (Simatupang et al., 2021). Because it is a priority, Herry stated that education policy is the embodiment of the vision and mission of education based on human and political philosophy in the context of the people's political, social, economic, and cultural situation. Education policy is taken by the government or those who have the authority, so what is said and done by the government in education is what is carried out (Fazey et al., 2020).

Prasojo argues that education policy is a consideration based on a value system and several assessments of situational factors. These considerations are used as the basis for operating institutionalized education, and these considerations are also a general plan that is used as a guide for making decisions so that institutional goals can be achieved (Akmal et al., 2020). Education policy is undoubtedly a key factor for excellence and the existence of a country or nation in global competition, so education policy needs to be prioritized to be studied critically and comprehensively (Aavik, 2019). The same thing was conveyed by Olssen, Codd, and O'neil, stating that education policy in the twenty-first century is the key to global security, sustainability, and survival...education policies are central to such a global mission... to have competitiveness and economic value (Cawood, 2017). Margaret E. Goerzt defines education policy concerning the efficiency and effectiveness of the education budget (Ryu, 2019).

Based on the explanation above, it can be concluded that education policy is a decision made by the government or organizers in the field of education as a reaction to the emergence of various educational problems that become a guideline for acting and as solutions and innovations to achieve the vision and mission of education from the government and other actors who take care of education.

\section{METHOD}

The research was carried out using a qualitative approach. Data was collected through the library research method. In a library, data is obtained by examining the related literature in the form of articles, books, documents and observing online literature. Furthermore, the data were analyzed and discussed according to the themes discussed. This research will focus on Indonesia's mechanism, implementation, and challenges in implementing an independent campus education policy.

\section{RESULT AND DISCUSSION}

\section{Independent Campus Policy}

Independent Campus is defined as a form of autonomously granting freedom to educational institutions and independence from complicated bureaucracy and freedom for students to choose the desired program (Aithal \& Aithal, 2020). The big 
goal to be achieved by the Ministry of Education and Culture is creating an autonomous, non-bureaucratic culture of educational institutions and creating an innovative learning system based on the interests and demands of the modern world (Ana et al., 2021).

This policy gives excellent hope for universities to develop quickly and be able to develop the quality of institutions. Higher education autonomy is a hope that various universities have long voiced. The complicated bureaucracy in middle and lower-class universities will be resolved with this policy. There are at least four major programs that the Ministry of Education and Culture will soon launch, these policies are:

a. Opening of New Study Program

The policy of opening new study programs is a step from the Ministry of Education and Culture to make it easier for State Universities (PTN) and Private Universities (PTS) to develop their study programs with less complicated bureaucracy. This policy is directed so that the proposed study program can be following the demands of the region, industry, and the world of work in general. This policy is expected to reduce the potential for graduates of study programs who are not absorbed in the world of work, thereby increasing the potential for unemployment in Indonesia. Study programs that have met the requirements under Permendikbud No. 7 of 2020 concerning the Establishment, Amendment, Dissolution of State Universities, and the Establishment, Amendment, Revocation of Permits for Private Universities Article 24 paragraph 2 will automatically get "Good" accreditation from the National Accreditation Board.

b. College Accreditation System

Higher Education Accreditation is the government's effort to standardize the quality of higher education and study programs. The existence of this accreditation indirectly requires universities and study programs to continuously and structured develop their quality, especially in the aspects of the tri dharma of higher education (Education, research, and community service).

The accreditation system in Indonesia per Law No. 12 of 2012 concerning Higher Education requires the extension of accreditation of higher education institutions and study programs to see the institution's quality development progress. However, the reality in universities today is that the five-year extension of accreditation has become an onerous burden, thus draining all available resources at the university. This is counter-productive because the available resources are forced to prepare accreditation tools and physical documents.

The Minister of Education and Culture Nadiem Makarim made a breakthrough against the current accreditation pattern, where newly established study programs will automatically get a C accreditation "Enough" until the PT or study program applies for re-accreditation. Provide a statement that the new 
study program will automatically obtain $\mathrm{C}$ accreditation from BAN-PT without waiting for the Ministry's approval. The accreditation is valid from the beginning until the study program proposes repairs or re-accreditation, the basis of which is Permendikbud No. 5 of 2020 concerning Accreditation of Study Programs and Universities.

New universities and study programs that have received "C" accreditation based on the approval of the Minister have the right to apply for reaccreditation. At the same time, if the college or study program fails to meet the qualifications to advance to a good "B" rank, they are required to wait two years after the decision is issued. According to various parties, these two years are feared to cause problems for universities or study programs in accepting new students. Another Nadiem Makarim policy that the author finds very encouraging is that universities and study programs that have received quality recognition from international accreditation agencies recognized by the Ministry automatically get accreditation of A. Among the international accreditation agencies recognized by the government are EQAR, CHEA, USDE, Washington Accor, Sydney Accord, WFME, and more.

c. Legal Entity State Universities

Nadiem's third "Learning Independence" policy aims to make it easier for state universities (PTNs) that are not yet legal entities to become state universities with legal entities. The Ministry of Education and Culture makes easy administrative requirements and helps PTNs change their status to legal entities. This policy is expected to spur PTN to continue to develop its potential.

d. Student Learning Rights for 3 Semesters Outside the Study Program

This Ministry of Education and Culture policy provides freedom and autonomy for students to take semester credit units (SKS) outside the study program they take and outside the campus. Various groups appreciate this policy because it is considered capable of providing opportunities for students to develop their knowledge and experience in the subjects they want.

This policy requires universities to give students the freedom to take credits outside the study program in the same campus for one semester or equivalent to 20 credits and outside the university for two semesters or equivalent to a load of 40 credits.

\section{Independent Campus Policy Implementation}

There are many examples of the implementation of the Independent Campus policy that several universities have implemented. Through the Independent Campus, it can be found that there are benefits that can be obtained, both by students, teaching staff, or outside parties who are involved. The following is a form of implementation of several universities in applying the Independent Campus policy:

a. Independent Campus Application by the Faculty of Teacher Training and Education, Ahmad Dahlan University 
The Faculty of Teacher Training and Education, Ahmad Dahlan University, has carried out four of the eight learning activities in the Indonesian Language and Literature Education Study Program (Sudaryanto et al., 2020). The applications are editing internships in the Editing course; teaching assistance in education units in the Introduction to School Field 2 course; research/research in Language Research, Literary Research, and Educational Research; and building a thematic real work village/college in KKN courses.

1). Editing internship in the Editing course. The editing internship was held at the publishing office of Samudra Biru and K-Media, Yogyakarta. The duration of the internship is eight hours, from 09.00 until 17.00 WIB. The activity was carried out per group per day, meaning that the internship groups changed every day. There are 4-5 students per group. They practice internships in editing fiction and non-fiction book manuscripts, depending on the wishes of the publisher.

After the editing internship is complete, all students participating in the Editing course make a work report and then present it before the lecturer. In his presentation, students will convey that they have found errors in written Indonesian in the manuscripts they edit. The errors in written Indonesian include writing words, using punctuation marks, and writing absorption elements. The editing internship report is considered equivalent to the final semester exam (UAS) for the Editing course. Then students get an editing internship certificate from the two publishers above.

2). Teaching assistance in academic units in the Introduction to School Field Course (PLP). The PLP I and PLP II participants are all students in the FKIP UAD and FAI UAD environments. Specifically, for FKIP UAD, there are students from 11 study programs, including Guidance and Counseling Study Programs, Indonesian Language and Literature Education, English Language Education, Pancasila and Citizenship Education, Physics Education, Biology Education, Mathematics Education, Elementary School Teacher Education, Education Teachers for Early Childhood Education, Automotive Technology Vocational Education, and Electronics Engineering Vocational Education. Specifically for FAI UAD, there are students from the Islamic Religious Education Study Program. The students in FKIP UAD and FAI UAD carry out PLP I and PLP II at the junior high school (SMP) and high school (SMA)/equivalent levels, both schools under the auspices of Muhammadiyah and schools under the auspices of non-Muhammadiyah. One of those schools is SMA Muhammadiyah 3 Yogyakarta.

3). Research/research in the subjects of Language Research, Literary Research, and Educational Research. Since semester six, students of the PBSI FKIP UAD Study Program have researched by making thesis proposals for the three courses mentioned above. Furthermore, the thesis proposal is selected by the Study Program lecturer team and distributed to all thesis 
supervisors. On average, each supervisor gets 9-10 thesis proposals/students.

They were building a thematic real work village/college in KKN courses. One of the students of the PBSI FKIP UAD Study Program by Wahyu Widayati carried out KKN in Panggul Kulon Hamlet, Candirejo Village, Semanu District, Gunungkidul Regency, Special Region of Yogyakarta. In that area, he scheduled the Indonesian Literary Literacy work program at the Baiturrahman Mosque on February 6, 2020. In short, he provided reading material in the form of short stories (short stories) for elementary school children in grades I to grade VI, numbered 15 people. During the activity, he observed that some children were not fluent in reading aloud. He worked around this by providing illustrated stories so that the children were interested and enthusiastic about reading the text.

Apart from Wahyu Widayati, there is also Risza Amalia who carried out Community Service Program in Panggul Wetan Hamlet, Candirejo Village, Semanu District, Gunungkidul Regency, Special Region of Yogyakarta. In that area, he held a Poetry Writing Training and Poetry Writing Competition at the KKN Command Post with the poem "Kasih Sayang." Through these two activities, he succeeded in generating interest in writing poetry for children in Panggul Wetan Hamlet, one of which was the inclusion of the poem "Dear Father and Mother" by Septiara Puspita Dewi, a 5th-grade student at SDN Gunungkunir I, Panggul Wetan, Candirejo, Semanu, Gunungkidul in the Kedaulatan Rakyat newspaper edition of March 3, 2020.

b. The Independent Campus Application through the Primary School Pioneer Teaching Village (KMP) by the Nahdatul Ulama Islamic University with the Primary School Teacher Education study program.

The Pioneer Teaching Campus (KMP) is one part of the Independent LearningIndependent Campus (MBKM) program organized by the Ministry of Education and Culture (Widiyono et al, 2021).

The implementation of the Pioneer Teaching Campus activities begins with selecting students at the Study Program and Faculty level. At the Nahdlatul Ulama Islamic University, the selection was made for Elementary School Teacher Education (PGSD) and English Education (PBI) students at the Tarbiyah and Teacher Training Faculty. Based on the election results, 10 PGSD students and 14 PBI students were selected. Then the 24 students do the filing based on various requirements determined by the Ministry of Education and Culture. Student data collection is carried out by the Field Supervisor (DPL) and verifying school data.

After completing the filing, students attend an online briefing by the Ministry of Education and Culture by bringing in resource persons who are competent in their fields for five days. The Minister of Education and Culture then released the assignment of KMP students to carry out their duties in assisting 
teachers and school principals in carrying out the learning process or school administration during the Covid-19 pandemic. After following the discharge, the students carry out their duties at the destination school.

The KMP program is related to implementing the Independent Campus, namely to have a relationship between the world of universities and the real world or the world of work. The KMP program hopes that students become agents of change who can inspire the community and of course, help schools to survive in carrying out their learning by transferring the application of technologies controlled by students.

Implementing independent learning through the pioneering teaching campus at SDN 01 Sowan Lor requires adaptation when KMP students are first deployed. The purpose of implementing the independent learning program itself is to focus on improving students' integrated literacy and numeracy skills. Due to the impact of the COVID-19 pandemic, students' understanding of literacy and numeracy material has decreased slightly so that the existence of KMP students can positively impact student learning outcomes.

KMP students can help teachers carry out learning following the learning objectives that have been prepared and can use a variety of mixed learning media according to the needs and abilities of students in learning activities. In addition to learning media, variations in learning models are also an effort to provide meaningful learning for students amid the COVID-19 pandemic. Students are also very interested in the learning provided by KMP students, even their interest in learning is immensely increasing.

The KMP program is considered capable of providing mutually beneficial benefits between elementary schools and students. According to the Ministry of Education and Culture, by joining this program, students have the opportunity to hone their interpersonal skills and gain teaching experience. In addition, elementary school students can interact and be inspired by teaching students who take part in the KMP program. For ten weeks from October 12, 2020 , to December 18, 2020, students are expected to help the learning process more effectively while increasing public literacy on the importance of health protocols in a pandemic.

The teachers and principals of SDN 01 Sowan Lor are grateful and grateful to the KMP students assigned there. This is because KMP students are beneficial both in the implementation of learning and administration in schools. The success of the KMP program is expected to continue to motivate students to carry out the next Teaching Campus program.

\section{Challenges in the Implementation of Independent Campus Policies}

a. Collaborative Mechanism between Private Islamic Universities and Study Programs with Outside Parties.

The policy of opening new study programs, university accreditation, and study programs are the two visions of the Minister of Education and Culture, which 
private universities appreciate (Fadli \& Akbar, 2020). This policy provides a breath of fresh air in complicated bureaucracy and requirements for submitting new study programs and accreditation. On a practical level, one requirement that requires collaboration between private universities and study programs with outside parties (service companies, industry, communities, other universities, and government and private agencies) creates confusion in the mechanism. This is not a big problem for large private universities, but for small private universities, this obligation raises its own problems.

Several questions arise among small private or private universities that fall into the disadvantaged, outermost, and remote categories, 1) how do private universities cooperate with service companies and large industries? 2) Do large PTS and PTNs want to collaborate with small PTS or PTs with accreditation of A collaborate with PTs that only have B or C accreditation?

The government should consider this issue to find solutions and regulations for collaboration mechanisms to make it easier for small private universities to collaborate with institutions and large universities. Small private universities with limited human resources, infrastructure, and especially private universities with remote geographical locations, certainly have significant obstacles to collaborating with large agencies and leading universities to realize productive and meaningful collaboration for scientific development and student experience. Without a precise mechanism and a shared vision between the Ministry of Education and Culture and other Ministries, this policy is considered only good in terms of regulations but creates problems at the practical level.

b. Acceleration of State Universities (PTN) Go International with the policy of PTN Legal Entities (PTN-BH)

The PTN-BH policy gives excellent hope for universities to create universities that are ready to compete internationally (Sandy \& Shen, 2019). The previous PTN-BH policies were felt to be very rigid and heavy, including that PTNs had to get A accreditation before they could become PTN-BH, the majority of PTN study programs had to be accredited A before becoming PTN-BH, Public Service Agency PTNs (PTN BLU) and Satker lacked financial flexibility, curriculum, and policy compared to PTN-BH. In this "free learning, independent campus" policy, Nadiem cuts down on the bureaucracy and complicated requirements, there is no minimum accreditation limit, and the flexibility in submitting PTN-BH as long as the PTN feels ready and meets the qualifications to transfer status.

This policy is expected to spur PTNs to become a world-class universities. This policy is expected to spur PTN to become a world-class university. Currently, there are only eight state campuses that are included in the 1000 best international campuses. Seeing this reality, the government must dare to set a high target for PTN with easy bureaucracy and sufficient budget supply to go international, not only to compete domestically. 
c. Internship Mechanism Outside the Study Program

The internship policy for three semesters outside the study program and PT is a visionary policy of the Minister of Education and Culture to provide freedom for students to develop scientific and work experience and socialize (Suhartini et al, 2020). At the practical level, several problems arise for small private universities or universities with remote, outermost, and disadvantaged geographical locations. In addition to the problem of the collaboration mechanism between study programs and universities and major study programs (referring to the level of accreditation) and large institutions, according to point two above, questions arise among study programs and students. How is the financing mechanism for the internship activity?

Most universities and study programs with the above categories have students with middle to lower family economic levels, internship financing is a big problem. Internship activities at least require transportation costs and costs to support other activities.

\section{E. CONCLUSION}

The visionary policy of "Freedom of Learning, Independent Campus" Minister of Education and Culture includes 1) opening new study programs, 2) higher education accreditation system, 3) freedom to become a PTN-BH, and 4) the right to study for three semesters outside the study program, giving high hopes for private universities to be able to develop their quality quickly. This visionary policy deserves to be appreciated, especially with the background of the Minister of Education and Culture, who is not from the world of education, he can provide a policy that various groups feel to be able to bring the progress of Indonesian universities. Among the challenges of implementing the "Merdeka Belajar" policy is 1) the collaboration mechanism between PTKIS and study programs with parties outside the campus; 2) paradigm shift in state universities with legal entities to compete on an international scale; 3 ) internship mechanism outside the study program.

\section{REFERENCES}

1. Aavik, K. (2019). Crafting neoliberal futures in the strategic plans of Estonian universities. Futures, 111, 148-158.

2. Aithal, P. S., \& Aithal, S. (2020). Analysis of the Indian National Education Policy 2020 towards Achieving its Objectives. International Journal of Management, Technology, and Social Sciences (IJMTS), 5(2), 19-41.

3. Akmal, M., Bambang, S., \& Indah, M. L. (2020). Direct and Simultaneous Regional Head Election in Indonesia with Government Efforts to Build a Balance of Political and Managerial Approaches. East Asia: An International Quarterly, 37(3), 261-279.

4. Ana, I. D., Agus, C., Suryatmojo, H., Widyatmanti, W., Aluicius, I. E., Kusumawardani, S. S., ... \& Kusumandari, A. (2021). Innovative and Sustainable Research-Based Learning \& Community Services During Lockdown by COVID- 
19. In COVID-19: Paving the Way for a More Sustainable World (pp. 257-279). Springer, Cham.

5. Cawood, F. T. (2017). Policy elements for twenty-first century African mining: Strengthening the existing African mining vision themes with cross-cutting subsets. Journal of Science and Technology Policy Management.

6. Digdowiseiso, K. (2018). Reexamining the Economic Growth-Education Inequality-Income Distribution Nexus in Indonesia. Journal of Applied Economic Sciences, 13(4 (58)).

7. Digdowiseiso, K. (2020). The Development of Higher Education in Indonesia. International Journal of Scientific \& Technology Research, 9(2).

8. Dunaev, V. Y., Kurganskaya, V. D., \& Shaikemelev, M. S. A. (2018). Integration of scientific and educational space in the Republic of Kazakhstan. Studia Politologiczne, 48, 212-228.

9. Fadli, U. M. D., \& Akbar, M. (2020). Phenomenology Study on The Formulation of A Vision to Achieve The Future of The University. IJHCM (International Journal of Human Capital Management), 4(2), 11-26.

10. Fazey, I., Schäpke, N., Caniglia, G., Hodgson, A., Kendrick, I., Lyon, C., ... \& Saha, P. (2020). Transforming knowledge systems for life on Earth: Visions of future systems and how to get there. Energy research $\mathcal{E}$ social science, 70, 101724.

11. Hidayat, S. E., Samidi, S., \& Nasution, A. (2021). The Alignment And Misalignment of The Islamic Economics Curriculum With The Indonesian Government Policy. Share: Jurnal Ekonomi dan Keuangan Islam, 10(1), 61-83.

12. Jaenudin, R., Chotimah, U., Farida, F., \& Syarifuddin, S. (2020). Student Development Zone: Higher Order Thinking Skills (Hots) in Critical Thinking Orientation. International Journal of Multicultural and Multireligious Understanding, 7(9), 11-19.

13. Morrar, R., Arman, H., \& Mousa, S. (2017). The fourth industrial revolution (Industry 4.0): A social innovation perspective. Technology Innovation Management Review, 7(11), 12-20.

14. Posselt, J., Hernandez, T. E., Villarreal, C. D., Rodgers, A. J., \& Irwin, L. N. (2020). Evaluation and decision making in higher education: Toward equitable repertoires of faculty practice. Higher Education: Handbook of Theory and Research: Volume 35, 163.

15. Prahani, B. K., Deta, U. A., Yasir, M., Astutik, S., Pandiangan, P., Mahtari, S., \& Mubarok, H. (2020). The Concept of" Kampus Merdeka" in Accordance with Freire's Critical Pedagogy. Studies in Philosophy of Science and Education, 1(1), 21-37.

16. Radianti, J., Majchrzak, T. A., Fromm, J., \& Wohlgenannt, I. (2020). A systematic review of immersive virtual reality applications for higher education: Design elements, lessons learned, and research agenda. Computers $\mathcal{E}$ Education, 147, 103778.

17. Rao, S. S., Loeb, A. E., Amin, R. M., Golladay, G. J., Levin, A. S., \& Thakkar, S. C. (2020). Establishing telemedicine in an academic total joint arthroplasty practice: 
needs and opportunities highlighted by the COVID-19 pandemic. Arthroplasty today, 6(3), 617-622.

18. Ryu, J. E. (2019). Impacts of Outcome Targeting in School Aid on Equity in School Spending and Performance Scores. Journal of Education Finance, 45(1), 57-79.

19. Sandy, W. (2018). Factors Influencing Indonesian Students Satisfaction during Their Studies in China. Asian Journal of Contemporary Education, 2(2), 136-148.

20. Sandy, W., \& Shen, H. (2019). Publish to earn incentives: How do Indonesian professors respond to the new policy?. Higher Education, 77(2), 247-263.

21. Simatupang, M. Y., Desi, S. N. Y. W. L., Basana, U., \& Nainggolan, T. (2021, January). Analysis of Smartphone Policy as a Learning Media on Community Health Study Program in STIKES Nauli Husada Sibolga. In 6th Annual International Seminar on Transformative Education and Educational Leadership (AISTEEL 2021) (pp. 571-575). Atlantis Press.

22. Sudaryanto, S., Widayati, W., \& Amalia, R. (2020). Konsep Merdeka BelajarKampus Merdeka dan Aplikasinya dalam Pendidikan Bahasa (dan Sastra) Indonesia. Kode: Jurnal Bahasa, 9(2).

23. Suhartini, R., Indarti, U. W. Y. I. R., \& Prihatina, Y. I. (2020). The Fashion Design Curriculum: Implementing the Learning Freedom and COVID-19 Pandemic Era. Learning.

24. Suharyono, S., \& Digdowiseiso, K. (2021). Education and gender wage gap: Evidence from Indonesia. Accounting, 7(1), 33-40.

25. Widiyono, A., Irfana, S., \& Firdausia, K. (2021). Implementasi Merdeka Belajar Melalui Kampus Mengajar Perintis di Sekolah Dasar. Metodik Didaktik: Jurnal Pendidikan Ke-Sd-An, 16(2). 